\title{
Exposure: the ethics of making, sharing and displaying photographs of human remains
}

\author{
John Harries, Linda Fibiger, Joan Smith \\ University of Edinburgh
}

Tal Adler, Anna Szöke Humboldt-Universität zu Berlin

j.harries@ed.ac.uk

\begin{abstract}
This article will query the ethics of making and displaying photographs of human remains. In particular, we will focus on the role of photography in constituting human remains as specimens, and the centrality of the creation and circulation of photographic images to the work of physical anthropology and bioarchaeology. This work has increasingly become the object of ethical scrutiny, particularly in the context of a (post)colonial politics of recognition in which indigenous people seek to recover dominion over their looted material heritage, including the remains of their dead. This ethical concern extends to the question of how and under what circumstances we may display photographs of human remains. Moreover, this is not just a matter of whether and when we should or should not show photographs of the remains of the dead. It is a question of how these images are composed and produced. Our discussion of the ethics of the image is, therefore, indivisible from a consideration of the socio-technical process by which the photographic image is produced, circulated and consumed.
\end{abstract}

Key words: Ethics, photography, human remains, art, archaeology

\section{Introduction}

Our article is about photographs of human remains. We are concerned with the rights and wrongs of making, sharing and displaying such photographs. As such, this article sits at the intersection of two discussions. The first is the discussion of the rights and wrongs of the public display of 'real' human remains in museums and galleries. The second concerns the rights and wrongs of photographing others and in particular the ethics of displaying photographs of the dead and dying. These two discussions are, of course, closely allied; yet, despite the fact that human remains are much photographed and these images are variously brought before the public in museums and galleries as well as online and in print, there is little consideration of the ethics of making and displaying such photographs and, more specifically, of making and displaying photographs of dry bones. In addressing the rights and wrongs of displaying photographs of human remains we are, therefore, in part raising the questions of how to bring these two discussions into conversation 
and to what extent, if at all, we can extend ethical concerns and guidance relating to the display of actual human bones to the display of photographs of human bones.

The concern with the ethics of making and displaying images of human remains emerges from our own practice. The authors of this article come from diverse backgrounds. Some of us are artists. Some are bioarchaeologists or physical anthropologists. Some are social or cultural anthropologists. We have been brought together by a shared interest in human remains - what they may reveal about past lives and how they inhabit contemporary culture. This shared interest has given rise to a shared project, entitled Dead Images. At the heart of this project is the ambition to curate an exhibition which features a 30-metre long, life-sized high-resolution photograph, created by Tal Adler, of a glass-faced cabinet with roughly 8,000 skulls (or parts of skulls), which are sequentially numbered and arrayed on shelves in a corridor of the Natural History Museum of Vienna. ${ }^{1}$

We will return to a discussion of the questions raised by the intention to show such a photograph in the conclusion, but as a way into this discussion we will begin with another image, or collection of images. We are indeed brought together by our shared interest in human remains, even as this interest has been cultivated within distinct disciplines. One aspect of this shared interest is that, even previous to the project to display a photograph of a collection of craniological specimens, we each in our different ways have dealt in photographic images of human remains. They were and are part of our work as artists, anthropologists and archaeologists. One such image, an old photograph found in an archive, was unearthed by John in the course of his work and we will start with this photograph. Or, in fact, we will start without it, because the choice has been made not to include it with the text of this article and it is this decision, and the muddled thinking behind it, which initially animates our concern with the ethics of showing images of human remains.

\section{The body of a child}

For some years now John has been studying the ways in which the people of Newfoundland, Canada remember the Beothuk. The Beothuk were a people indigenous to the island of Newfoundland. They are now said (by most) to be extinct. The date of their extinction is conventionally given as 6 June 1829, when a young woman named Shanawdithit died in a hospital in St John's, then and now the capital and principal town of the island. ${ }^{2}$ The precise cause of this extinction is debated, but what is beyond debate is that the coming of settlers from England and Ireland, people whose descendants now consider themselves the 'natives' of Newfoundland, precipitated the annihilation of the indigenous people of the island. These settlers brought with them diseases and guns. Some may have cultivated a benign, if paternalistic, concern for the welfare of the benighted Beothuk. Others, however, were not so well disposed and engaged in acts of cruelty and slaughter. ${ }^{3}$

Despite (or maybe because of) this unfortunate history, after the death of Shanawdithit and the extinction of her people some of the English and Irish settlers and their descendants, who now considered themselves to be 'native' Newfoundlanders, set about remembering the Beothuk. This work of memory was and is material. 
It involves discovering and gathering together what remains of a 'vanished' people. Amongst these remains are bodies, or what is left of bodies, that have been found in the company of grave goods and beneath birch bark and loose stones. Years after the Beothuk 'disappeared' from the island inquisitive (or acquisitive) settlers looted these graves, pulling away earth and stone and sheets of bark and taking what they found. Some of this stuff was kept privately, but much of it found its way to cities and into the collections of museums and universities. ${ }^{4}$

One such looted grave was that of child. The grave was discovered in 1886 on an island lying at the entrance to Pilley's Tickle in Notre Dame Bay, one of the northern bays of the island of Newfoundland. It may have been discovered by 'geologists' surveying the island for copper or it may have been discovered by children picking berries. No matter. The grave was discovered and what lay therein was unearthed. Its contents included two little models of birch-bark canoes, a toy-sized bow and arrow, a packet of dried fish neatly wrapped and other such goods. It also included the body of a child, wrapped in a shroud fashioned from the caribou-skin sleeve of the coat of an adult. ${ }^{5}$ All these were taken away to St John's and into the collection of the museum that had been created by the geologist James P. Howley. He put the little body and the things that travelled with it on display in 'case 13', which also held the skull and 'arm bone' of an adult Beothuk and a profusion of stone spear points, axes and other 'implements'.

The museum of Newfoundland (eventually Newfoundland and Labrador) had a troubled history, suffering from neglect and closure and more neglect, the collection being moved from one place to another, scattered and then reassembled. But the little body and most of its grave goods survived these changes and, except when there was no museum at all, were on display to the public. The body may have been finally withdrawn from display in 1976, when the museum exhibits where once again renovated and redesigned. ${ }^{7}$ Nowadays the Museum of Newfoundland and Labrador is housed in a modern building of brown stone, blue-tinted glass and a red pitched roof designed to be reminiscent of the traditional 'salt-box' houses of rural Newfoundland. The little body is nowhere to be seen. It is still in the keeping of the province, but is held with other Beothuk remains in the archaeology department of Memorial University. Access to this space is severely restricted, with permission at a ministerial level being required to even view, let alone interact with, the Beothuk remains.

Being interested in how Newfoundlanders remember the Beothuk, John has been gathering archival material that relates to this story. In so doing he came across the mention of a photograph, originally taken in 1908 by Alfred Hugh Fischer and now held in the Royal Commonwealth Society Collections of the University of Cambridge. The archive entry reads:

Beothuk remains. Half-plate (landscape format). Found in a grave on small island called Pilley's Tickle in Notre Dame Bay. In foreground skeleton of a Beothuk man is seen, and on shelf looking down is an Esiquimau Kajak (Labrador) with a figure on it. ${ }^{8}$

He requested that a digital copy of the image be made and sent to him and it duly arrived on a CD-ROM. He clicked on the file and the image came before him in 
shades of grey. ${ }^{9}$ The camera's gaze is focussed on the child's body, which lies upon a plank of wood, supported at either end by display cases, one seeming to house shells and the other more bits of human bone. The body is mostly bone, although some skin still stretches across the shoulder and upper arms. It lies on its side, facing the camera, if the empty eye-sockets and nasal cavity are taken to be a face. Its knees are drawn up towards its chest. It seems that the shroud of caribou skin has been drawn aside so as to better see the body. This creates an odd effect, as if this child has been exposed, made naked before the gaze of the photographer and any who look upon the photograph.

This is not the only photograph of the body of the Beothuk child found on an island in Notre Dame Bay. A bit more online archival digging unearthed a digitised image held in the collections of the Provincial Archives of Newfoundland and Labrador. The image is entitled 'Beothuck Relics'. The archival entry describes this as an image of a 'Boudoir card' made sometime between 1870 and 1908 by S. H. Parsons, a cabinet maker-become-photographer who, by the turn of the century, operated a 'Photographic Studio and Fine Art Emporium' on Water Street in St John's. ${ }^{10}$ The image is sepia coloured and framed by a red border. In the centre is the body of the child, still curled in a foetal position but with the caribou-skin covering drawn up over the shoulders. Arranged about it are more and bigger human bones: a skull, some ribs, two long bones crossed. There are also pendants carved from bone, birch-bark containers, little model canoes, stone axe heads and scrapers and so on. A black and white photo of the child's body appears also appears on page 331 of James P. Howley's book The Beothucks or Red Indians of Newfoundland, first printed 1915. ${ }^{11}$ A locally published 'biography' of Demasduit by Bernard Fardy also features a photograph of the remains of the child, taken by the author himself on a visit to the Newfoundland Museum in 1976 and printed with the caption: 'mummified skeleton of a Beothuck child - buried in typical Beothuck death repose and sewn up in birch bark.' ${ }^{2}$

Nor is Fardy the only person to have taken a photograph of the body of the Beothuk child while visiting the museum. In response to a request for reminiscences by those who could remember seeing the child when on display, a woman named Glenys Cocker sent John a digital scan of a photograph taken by her husband in the early 1970s when he visited the museum as a ten-year-old schoolchild. It has the look of a photo taken by a child in the 1970s. It is out of focus. Its colours have faded into muted shades of pink, yellow and brown. With the photograph came Glenys's own memories of visiting the museum and seeing the Beothuk bodies. She writes:

As a child I visited the museum many many times with my parents and I remember well the Beothuk skeletons on display. Having never seen human remains before I was fascinated with them. It was a lot for a young child to absorb; that these were once living breathing people who lived here on this island long before anyone else did. I especially felt a deep sense of sadness for the child, whose body lay on its left side in a glass cabinet, almost in a foetal position, with a tiny 'doll' resting next to it. I remember the arms and other parts of the body appearing to still have what I thought was skin covering the bones - very dark and leather like. It was difficult to tell approximately 
how old the child was. From the size of the body it must have been fairly young. I couldn't help but picture he or she running and playing, having a family and parents who loved it. So very sad.

So, like memories, these photographs move (in both registers of the word) and may be shared, even as the little body itself has been withdrawn from public view, with any intimacy, any exposure, being tightly regulated. They move even more freely now that they exist digitally, allowing for unlimited reproduction, circulation and myriad possibilities for display. The body itself, the stuff of skin and bone, may, from the perspective of any but the select few, be gone, but the images go on, reproducing, proliferating, with the potential to enter the public domain more or less at the whim of the person who possesses a copy of the photograph, so long as they are mindful of the legalities of copyright.

The question, therefore, besides proprietorial concerns over images rights, is this: what, if any, ethical considerations should inform and impinge on the decision to reproduce and display photographs of the part-mummified body of the Beothuk child or, indeed, any human remains? Should we, for example, insert the photographs taken by Alfred Hugh Fisher or S. H. Parsons or Glenys Cocker's husband into this paper so as to share them with any who may read it? After all, we can see them. In crafting the descriptions of the photographs we moved back and forth between the image and the emerging text, opening one file and then the other, tweaking the descriptions so that they roughly correspond with what we see (and don't see) in the digital image. It is a curious and maybe perverse thing to withhold them. A picture is, as the cliché goes, worth a thousand words. Yet we have decided to withhold them - to not, for example, share the image of the small body laid exposed on a plank of wood suspended between two glass-covered display cases.

This is an ethical decision. We have chosen not to do so because it feels 'wrong', but these feelings are inchoate and somewhat whimsical. We could have equally decided, given the purpose of this piece and that it is intended for an academic journal which will largely be read by an academic audience, that it would be right and proper to have this photograph displayed alongside the text of our article. Maybe it would be wrong to have this image made into a postcard (or even a 'boudoir card'). Maybe it would be wrong to include it in a visual lecture to be given to school children (which was the original remit for Alfred Hugh Fisher's photographic exploration of the British Empire, which included a trip to the museum in St John's ${ }^{13}$ ). But in a scholarly journal, maybe it is OK? Alternatively, maybe it is the composition, rather than the content, of the image itself that is the problem? In contrast to the photograph taken by Fisher, the image in Howley's book corresponds to the epistemic aesthetics governing the appropriate photographic display of human remains as specimens. The body, laid on its side and facing the camera, is pictured against a creamy-white background. It is pure, lifted away from the architecture and detritus of display - no plank of wood, no cases of shells or squid in glass jars - and joined only by the things that accompanied it into the afterlife and then on its trip to St John's. Maybe this is a less 'difficult' image and so more appropriate for reproduction within the pages of an academic journal? 
The point is that, in contrast to the considerable body of writing and institutional guidance concerning the rights and wrongs of displaying human remains in the flesh (and skin and bone), the reproduction and publication of images of human remains has received next to no attention. This leaves those of us who, in our various ways, trade in such images - gathering them to us, integrating them into our work, whether that work be anthropological, archaeological or artistic, and, through this work, sharing them with others - to negotiate ethical questions according to our rough, and often inarticulate, sense of what we should and should not do. In addressing the images of the body of a Beothuk child, unearthed and exposed at the close of the nineteenth century, as well as other images of human remains that we are creating and working with, we wish to render this ethical sense more articulate to think about, if not resolve, the rightness and wrongness of the ways in which we work with photographs of the remains of dead bodies.

\section{The ethics of handling and displaying human skeletal remains}

One possible way to respond to these ethical questions concerning the making, circulation and display of images of human remains is to turn to the better-developed guidance relating to the handing and display of 'actual' remains, particularly in the archaeological and museological context. So, who interacts professionally with archaeological human remains on a daily basis, and what guides this interaction? Various legal obligations as well as codes of ethics, codes of practice and policy documents exist. ${ }^{14}$ These documents are generally created by museums and higher education authorities, as well as professional bodies and cultural heritage associations. This section focusses on the aims and limitations of regulations and guidelines for the handling, storage and display of human remains. It will focus mostly on the situation in England as a case study to exemplify some of the issues involved.

These days, human skeletal remains arrive in heritage and higher education institutions as a result of commercial or research-related archaeological work, although the former is responsible for the majority of more recently excavated remains in collections. Legislation recognises the special status of human remains within the large body of material recovered during archaeological work. A special licence, issued by the Ministry of Justice, is required for the excavation of human remains in England and Wales. ${ }^{15}$ Once remains are removed from an archaeological site, they become the responsibility of the company or institution analysing and curating them. This can include commercial archaeological companies, national and local museums and university departments, all of which operate in accordance with in-house policies and guidelines, ${ }^{16}$ and/or adapt those issued by national of international governments and heritage bodies, ${ }^{17}$ which themselves often refer to or implicitly embrace wider, internationally recognised standards and practice. ${ }^{18}$ These documents contain advice on wide-ranging issues, from the practical (e.g. legal obligations and limitations; best practice related to health and safety, short- and long-term storage and analytical methodology and standards) to the more complex and at times less tangible issues of consent, respect, cultural affiliation, ownership and the merits and prospects of scientific engagement with the remains. ${ }^{19}$ Closely linked with the latter 
are concepts of academic freedom, i.e. the idea of the right to pursue research and the parameters in which this is acceptable - especially with regard to extant populations with cultural or spiritual links to the skeletal populations in question or in situations of perceived or experienced unequal power relationships, past or present, relating to colonial heritage. ${ }^{20}$

An often-explored issue with regard to archaeological human remains are the questions of if and how these remains may be displayed to the wider public, which is as much about appropriate interaction with the remains of the dead (reflected in the - for lack of a better concept - often referred-to importance of respect), as it is about concerns with how members of the public may experience this encounter with the dead - the 'body in a museum. ${ }^{21}$

While this article cannot explore in depth all of the complex and culturally diverse ideas around human remains as symbolic objects, ${ }^{22}$ at a very basic level a look at skeletal remains, no matter what their chronological age or cultural origin, creates a link with our own body and its mortality. ${ }^{23}$ While surveys have shown that there is broad public support for the display of human remains in museums in general, ${ }^{24}$ these surveys do not usually capture more intrinsic data about whether people feel equally comfortable with all types of human remains, but a 2001 survey by Rumsey asked the pertinent question of what types of remains people would rather not like to see in a museum. ${ }^{25}$ At the top were medically preserved remains as well as remains of babies, probably highlighting the difference in attitudes towards skeletonised remains and those with soft tissue (which are also much easier to recognise as identifiable individuals to a non-specialist), as well as a recognition of children and infants as vulnerable and inherent protective instincts towards them. At the same time, a visitors' survey relating to the display of a skeletal series of foetuses and children at the National Museum of Health and Medicine in the United States, consisting of interviews rather than a simple lists of short questions, generated responses that reflected curiosity rather than distress about the origins and fate of the individuals displayed (e.g., how did they die? How did their remains get to the museum?) ${ }^{26}$

No matter what the institution displaying the remains, there have always been dedicated concerns about doing things the right way, ethically and professionally. Many museums increasingly use the concept of sign-posting, i.e., raising awareness of the presence of human remains so as to avoid people coming across them unaware (for a good example see the National Museum of Ireland exhibition 'Kingship and Sacrifice ${ }^{\prime 27}$ ). Images of human remains, digital ones in particular, are of course much more difficult to sign-post, especially once they enter the World Wide Web. Interestingly, policy and ethics guidance for images of skeletal remains is more limited and, if existing, much broader than that for actual remains. ${ }^{28}$ The UK government's Department for Culture, Media and Sport (DCMS) guidance mentions that 'in considering any photography, views of cultural communities and genealogical descendants should be considered where known. ${ }^{29}$ This is often not possible with archaeological remains of considerable time-depth, while as recently as 2014 Antoine highlighted that 'the use of images of human remains is seldom discussed in guidance documents or most of the relevant literature and would benefit from further debate ${ }^{30}$ This state of affairs that does not seem to have changed significantly 
in the intervening years. Like the DCMS guidelines, Antoine goes on to underline the British Museum's concern with cultural sensitivity and restrictions to film and photography within the museum - which does not address many of the issues raised by the image of the Beothuk child: without obvious descendants (if considering the Beothuk extinct), there is nobody to consult; The individual is a child does that make a difference? There is preserved soft tissue - does that alter how we should approach this image? Is this an appropriate image of human remains in terms of its composition, the way in which and where the body is arranged/displayed? The image is clearly a historic one - would and should there be a different way of photographing the body now - and if so, different in what way?

Disclosed within these questions is a more general problematic. To what extent can we extend the ethical guidance that pertains to the handling and display of 'real' human remains to photographic images of these remains? The paucity of guidance relating to such images suggests two possibilities. The first possibility is that images of human remains are like human remains and in their likeness the ethical considerations which inform the display of 'real' human remains should likewise inform the display of images of human remains. So, if the decision to put a child's body in a glass case and set that case before the gaze of the public should be mindful of public sensibilities and, in particular, the thoughts and feelings of those people who are kindred to that child (however that kinship be articulated and recognised), we must be similarly considerate of public sentiment and 'the views of cultural communities and genealogical descendants' when thinking about circulating and showing an image of that body.

The second possibility is that in its likeness the image is somehow not so much a worry, and that even as we may extend the same ethical considerations from the body to photographs of the body they are nonetheless different. So, given that our ethical concerns are articulated with reference to the substance of the body as thing of skin and bone that even in decay bears the traces of vital being, such concerns fall away, or soften, when we deal in images, which are, after all, something other than the real thing. The fact is that, even though these two positions would seem antithetical, they both hinge on how we conceptualise the relationship between the photographic image and the thing photographed. In particular, we would suggest, they both hinge on the notion of likeness and the centrality of an epistemology of depiction when considering the nature and value of photographs of human remains.

\section{Transparency, proximity and appropriation}

One question that preoccupies those who are given to thinking philosophically about the nature of the image is how, if at all, photographs may be considered to be a different kind of image to, say, a line drawing. In other words, and to quote Kendall Walton, 'what is ... special about photography?' ${ }^{31}$ One answer to this question seems to be that photographs are different because of the quality of the relationship between the image and the thing it depicts.

For Walton, who draws much inspiration from a foundational article by André Bazin, ${ }^{32}$ what distinguishes the photograph is its 'realism. This is, however, not 
realism understood as verisimilitude or accuracy (after all, as Watson notes, if this were so, then some drawings may be much more 'realistic' than some photographs). ${ }^{33}$ Photographs are, rather, realistic because they are 'transparent', in the sense that we 'see the world through them. ${ }^{34}$ This quality of transparency is bound up in the mechanical nature of photography as a means of capturing and conveying an image of the world out there and, by extension, the 'ontological commitment' of the photograph, the fact that it can only and ever be an image of something that was there before and beyond the image. This commitment means, as Susan Sontag argues, that the identification of the subject of the photograph always dominates our perception of it. ${ }^{36}$ In this respect, unlike a drawing or a written description, photography is a medium for perceiving the world in that it allows us or anyone who views a photograph, no matter how poorly focussed or distorted, to make 'perceptual contact' with that world, to see through the photograph towards its subject, in a way that a depiction or description crafted by an artist or author cannot. So, if we return to the example of the bodily remains of the Beothuk child, our written description, even in its aspiration to accuracy, does not allow the reader to perceive the body, while the inclusion of a photograph, even the out-of-focus photograph taken by a ten-year-old boy, would.

Mikael Pettersson takes up this line of argument to suggest that, phenomenologically, the photograph allows a sense of proximity or intimacy with that which is photographed. This is an intimacy conveyed through the lighted air and the transformation of the surface upon which the image materialises. There is, and here Pettersson quotes Roland Barthes, 'a sort of umbilical cord' which 'links the body of the photographed thing to my gaze: light, though impalpable, is here a carnal medium, a skin I share with anyone who has been photographed'. ${ }^{37}$ 'Photographs are, according to Pettersson, 'literally traces of what they are photographs of. ${ }^{38}$ In this sense photographs are epistemologically privileged not by virtue of their being a more 'accurate' depiction but in that they provide 'epistemic access to what they are of. ${ }^{39}$ None the less, to look upon a photograph is not the same as 'really' seeing something. The latter involves a spatial proximity - a being close by or coming face-to-face; however, as Pettersson argues, photographs,

by allowing us to see things in their surfaces, by offering quasi-illusionistic experiences of objects, trade on this connection between perception and spatial proximity, yielding, as a result, an experience of closeness to them. ${ }^{40}$

This play of distance and proximity, intimacy and detachment, hints at a certain ambivalence concerning photography and its relationship between the photograph and the thing (or person) photographed. Pettersson touches on this when he cites fanciful tales of 'savages' "who fear having their photograph taken due to the "archaic belief" that this would imply having their soul stolen. ${ }^{41}$ For Pettersson, this is to misunderstand the nature of photographic traces as imprints rather than substantial extensions of the thing itself. Nothing substantial is actually taken when one takes a photograph. What this suggests, however, is that, in a way wholly different to the perceiving of another within the context of the face-to-face encounter, the creation 
and circulation of this 'depictive trace' constitutes the possibility of losing possession of oneself or coming into the possession of another.

\section{Ethics and ambivalence of the photograph}

For Sontag, the photograph is distinguished from descriptive writing, painting and drawing not only by the illusion of transparency, achieved through the mechanics of 'taking' a picture, but also by it capacity to allow for the appropriation of the thing photographed in and through its image. She writes that,

To photograph is to appropriate the thing photographed. It means putting oneself in a certain relation to the world that feels like knowledge - and, therefore, like power. A now notorious first fall into alienation, habituating people to abstract the world into printed worlds, is supposed to have engendered that surplus of Faustian energy and psychic damage needed to build modern inorganic societies. But print seems a less treacherous form of leaching out the world, of turning it into a mental object, than photographic images, which provide most of the knowledge that people have of the look of the past and the reach of the present. ... Photographic images do not seem to be statements about the world so much as pieces of it, miniatures of reality that anyone can make or acquire. ${ }^{42}$

Sontag's critique of photography may have been developed in reference to war photography, and particularly photographs of the Vietnam War, ${ }^{43}$ but it also may be, and has been, ${ }^{44}$ extended to a critical engagement with photographs of the bodies of 'others' taken in colonial times and now residing in archives and museum collections in former imperial metropoles. In this context the 'taking' of pictures has been read as being closely allied with techniques of colonial governmentality and forms of voyeurism intrinsic to the ideological constitution of otherness. ${ }^{45}$

Much of more current scholarship regarding these collections has focussed particularly on their 'emotional afterlife' ${ }^{46}$ within postcolonial cultures of public memory in which, along with gatherings of human remains, archives of images of racial types and imperial brutality become a problematic 'colonial legacy ... felt as difficult, shameful, perhaps unspeakable. ${ }^{47}$ Given this framing, the value of photographs is argued to lie precisely in their capacity to elicit a sense of ethical proximity with the imperial past, thereby countering a tendency towards 'aphasia' ${ }^{48}$ or 'ignorance ${ }^{\text {'9 }}$ regarding the colonial histories of European nations. For example, a series of studies have addressed recent attempts to curate memories of colonialism in the Dutch East Indies through the public display of photographs taken at the time. ${ }^{50}$ This is a context in which, to quote Paul Bijl, 'Dutch colonialism and its violence sometimes appear as forgotten in the Netherlands because the victims of colonialism are not memorable within a national context and there is no language available to discuss them as a part of Dutch history. ${ }^{51}$ Against this culture of forgetting and denial, displays of 'colonial photography can be seen as calls upon the body politic to start more thoroughly addressing the uncomfortable pasts that keep haunting it.' ${ }^{52}$ 
Within this discussion, the question of the ethics displaying photographs of the bodies of the dead and dying is articulated and resolved with reference to what Elizabeth Edwards describes as the 'visual ecosystem of the museum ${ }^{53}$ and how these ecosystems may be created and curated to realise the potential of museums to act as 'agents of change' ${ }^{54}$ which, to quote Jill Bennett, are 'able to exploit forms of embodied perception in order to promote forms of critical enquiry. ${ }^{55}$ To an extent, engaging with the question of the rights and wrongs of displaying photographs in this register serves to set aside the ethical anxiety with appropriation argued by Sontag, which centres on the mechanical moment of exposure in which something is taken, appropriated from the world or, more particularly, from whoever is photographed. In this sense, there is some difference between how we think of ethical questions relating to the display of human remains in the museum and the display of photographs of the dead bodies. When it comes to the display of human remains, the issue of appropriation, of the literal and figurative 'taking' of human remains, is central to discussions about the rights and wrongs of the retention and display of bones. When it comes to photographs of bodies, including and especially the dead, the question of 'taking' is marginal to the consideration of the politics and ethics of the display of such photographs, with the emphasis being on what photographs do and how they elicit responses from the audience.

Beyond the context of the museum and gallery there has, however, been some discussion of the ethics of photographic appropriation. In these contexts, the moral anxieties engendered by the taking of someone's image are resolved by allowing for the person photographed to exercise some degree of ownership of their own photographic depiction, as they would of their own bodies or that stuff which is recognised to be rightfully theirs. For example, in considering the 'ambivalence' of ethnographic photographs, Joyce Hammond reflects on two sets of photographs that she took while doing fieldwork in Tahiti concerning tifaifai, a quilt-like fabric. The first are a series of 'candid close-ups of people expressing heartfelt emotion', taken during a 'formal departure. ${ }^{56}$ To her mind, they 'turned out very well in composition and technique', yet she has 'never published the pictures, keeping them only for personal pleasure of enjoying their aesthetics and the memories they evoked for me. ${ }^{57}$ She contrasts these images with some photographs she took at a wedding feast, where the subject, a tifaifai maker, agreed to be photographed and arranged things to her liking: changing her own clothes, insisting that her grand-daughter also change into some 'nice clothes' and posing formally in front of the tifaifai. ${ }^{58}$ Once the photograph was taken, Hammond 'provided the tifaifai-maker a copy' and 'carefully recorded her name and that of the granddaughter. ${ }^{59}$ The difference, of course, is that in the second example a photograph may have been taken, but it was not stolen. It was taken with permission, and moreover, the people being photograph arranged themselves in the full anticipation of becoming image. In this there was, to borrow a concept from Sten Langmann and David Pick, a 'dignityin-process', by virtue of the fact that the research participants were involved in the way images are captured, for example, choosing the right angle for an image, the right time to capture an image and the impression it will give if and when it is published. ${ }^{60}$ 
Similar considerations have informed discussions of the ethics of clinical photography, particularly in the context of the proliferation of digital technologies. ${ }^{61}$ As Ian Berle argues, photographs, in their depictive transparency, are of epistemic value in the clinical context. They have both 'therapeutic value, ${ }^{62}$ in that images are enrolled into the work of diagnosis and treatment, and 'non-therapeutic value,' ${ }^{63}$ as an aid to teaching or as illustrations in lectures and published papers. The problems, however, are several. There is a concern about 'an invasion of privacy, and especially, clinical photography because it reveals particularities that people would rather keep hidden. ${ }^{64}$ In this sense, the anxiety is one of 'exposure' and the peculiar capacity of photography, as a form of perception, to 'expose' the subject to the gaze of distant and unknown others. There is also a related concern with 'patient autonomy', ${ }^{65}$ which Berle, quoting Beauchamp and Childress, defines as 'self-rule that is free from both controlling influence by others and from limitations, such as inadequate understanding, that prevent meaningful choice. ${ }^{66}$ If the subject of a photograph, in this case a hospital patient, is to be exposed to the gaze of others through the medium of the image as a depictive trace, then they should choose to do so, in full awareness of the value and purpose of such exposure. As in the case of the ethnographic photographs discussed by Hammond, the key is informed consent and ensuring that the subject of the photograph has given their informed consent, thereby securing some quality of 'dignity-in-process' and undoing the potential violence or violation of appropriation.

The implications of this discussion for the ethics of making and displaying photographs of human remains are clear: if photographs have a peculiar epistemic value as a 'transparent' medium, a depictive trace, which allows the viewer a sense of intimacy and proximity with the subject of the photograph as that other who is within and beyond the image, then the ethical considerations which pertain to the handling and display of 'real' human remains would extend to the circulation and display of photographs of human remains. For clinicians the principal way in which these ethical anxieties are allied is through informed consent, a process by which one secures the 'dignity-in-process' of the subject of the photograph, be it a living person or the remains of a once living person. With this we return to the question of proprietorship and who, in the absence of the possibility of consent by the subject of the photograph, is authorised to speak on behalf of that subject.

As discussed above, this question of proprietorship is usually resolved with reference to idioms of kinship. Living people, in other words, may speak for 'their' dead and how the remains of their dead may be handled, disposed of or exposed, including exposed in and through the photographic image. In the case of the ancient dead, or dead who have no kin as recognised through normative pronatalist idioms of kinship, materialised as blood or DNA, ${ }^{67}$ then more expansive notions kinship such as 'cultural affiliation' are deployed to address and, hopefully, resolve questions concerning the appropriate treatment of human remains. Such processes of informed consent are complex and sometimes adversarial, in particular where the recognition of kinship and cultural affiliation is bound up with how we transact the complex legacy of colonial violence and dispossession and contemporary claims for recognition and restitution advanced by historically marginalised 
indigenous groups. This complexity does not, however, in itself undo the ethical requirement for informed consent, nor the suggestion that this requirement extends from the matter of human remains to photographic images of those remains.

\section{The ethics of unsettlement and photographic affect}

What we have left out of this formulation, however, is any consideration of the power of the photograph, in its transparency, in its capacity to solicit an experience of intimacy and proximity, to affect or move people. Such a consideration is vital to the discussion of the ethics of creating and displaying photographs of dead bodies in general and, in particular, in the art context.

One way to consider the affective capacity, the power, of the photographic image of human remains is, once again, to extend the guidance pertaining to the public display of 'real' human remains to the display of photographs of human remains. As discussed above, this guidance is mostly oriented towards the encounter with human remains not just as informational but as a coming face-to-face with human mortality. One may think of Glenys Cocker's memory of seeing the body of the Beothuk child displayed in a glass case in the old Newfoundland museum. 'So sad', she says, and the sadness seems to be about loss: the annihilation of a lively being materialised in the spectacle of the part-mummified body; a child haunted by the 'picture' of 'he or she running and playing' and 'having a family and parents who loved it'. There is a potential power to this encounter which requires careful mediation, especially when what is materialised is not simply the loss of the life of a child but, by extension, the extinction of an entire people.

As discussed above, in the archaeological context this is accomplished by screening the excavation of burial sites from public view and by creating viewing areas that somebody may choose or reject to enter. Similarly, in the museological context this is accomplished through signage and directives so that people should expose themselves to the potentially moving encounter with mortality only knowingly and by choice. There may, of course, be value in this affective encounter with human remains. Duncan Sayer, in particular, has argued that 'the public do not need to be protected from the ancient dead nor are they afraid of them ${ }^{68}$ and that the encounter with human remains while assisting with an archaeological dig or gazing on a display of bones in the museum may 'make an enriching contribution to modern society, facilitating a relationship with death, the dead and so the dying. ${ }^{69}$ So, rather than withdrawing the remains of the dead from public view, we should be bringing them into visibility, inviting an open, thoughtful, contemplative encounter with the corpse and, through the corpse, with the fact of human mortality. In considering displaying a photograph of human remains we may, therefore, decide to screen it off, to withdraw it, to hem it in with warnings so that people can choose to see or not to see, but we can also acknowledge that the photograph, as a depictive trace, may also allow for an experiential proximity with death that is, if Sayer is correct, somewhat lacking in our thanophobic society.

This, however, overlooks the curious ambivalence of the photographic image and its relationship with its subject. Photographs, as we discussed in reference to Sontag, 
are not simply ways of extending perception or provoking an illusory experience of intimacy; they are, by the very mechanics of production and reproduction, a machine of objectification, a technology of dispossession and alienation, a form of 'soft murder' ${ }^{\text {'70 }}$ as Sontag describes it. In practice we may seek to undo the potential for violence and (dis)possession that inheres in the relationship between the subject and the photographic image through routines of informed consent, whereby the creation, circulation and display of the photograph becomes an extension of the subject's agency. Another, possibility, however, is that the very ambivalence described by Sontag may be excavated and exposed through self-reflexive artistic practice which focusses not on conveying a sense of intimacy with the photographed other but on provoking this disquieting sense of ambivalence and transgression.

Andy Warhol, for one, understood the power of the photographic image and its ethical challenges. His training as a commercial illustrator taught him the manipulative nature of advertising and his interest in popular culture, and the aspirational mind-set of ordinary Americans helped to make him one of the leading figures in Pop art. But it was a dark side to popular culture that he brought to the fore when he appropriated press photographs of human tragedies to use in his own work. His 'Death and Disaster' series in the 1960s used photographs of car crashes and other accidents taken from newspaper front pages as a comment on the general public's macabre fascination with violent death and the cynical way that such images could be used to sell newspapers. ${ }^{71}$

The ubiquity of the types of photographs appropriated by Warhol, many showing car-crash victims entangled in the mangled metal of the car, was further emphasised by his use of screen-print as a method for repeating images. As the photograph was repeated the image became degraded. This degrading added to the intrigue: the slightly unclear photograph had to be deciphered, making it hard to tell whether you were seeing a human leg amongst the metal or just another part of the car. Although the degrading of the photograph veils some of the gorier detail, it also serves to dehumanise the subject further: man and machine become one, and both form a pattern on the canvas.

What made the representation of such subject matter particularly ethically challenging was the photographic medium itself. Had the images been drawn, the mediation of the artist would have somehow made the images less real, the source less well identified, the slowness of the technique more reverential and sensitive. The screenprint process, if anything, reiterated the brutality of the original photograph by its unquestioning and speedy repetition. In this case it is the photograph's verisimilitude, its cold objectiveness as well as its purpose as newspaper entertainment, that underlines the ethical question.

The photograph's further transformation into 'Art' increases, therefore, the objectification of the image of death, removing any reference to the actual people involved. For example, Andres Serrano's photographs of bodies in the morgue have the seductive grace of Renaissance paintings. In The Morgue (Knifed to Death II) the hands reference Michelangelo's God reaching to Adam in the Sistine Chapel; The Morgue (Rat Poison Suicide) is reminiscent of a crucifixion by Grünewald or Caravaggio. 
The morgue pathologist allowed Serrano to photograph the corpses on the condition that they were disguised to preserve their anonymity, and the subject matter is similar to Warhol's, showing the aftermath of violent death. However, Serrano crops, constructs and composes, covering with body with cloth or using lighting to focus attention on a particular detail before photographing and then printing in large format. There is both honesty and dishonesty here: the photograph is the means to capture vérité, but also to cut out irrelevant information. The photograph manipulates the viewer: we are seduced by the beauty of the image, then repulsed and upset when we learn more about the subject. Describing what he had learned by photographing the bodies in the morgue, Serrano stated: 'In a way, it's made me more at ease with the idea of dying. ... For me, these are not mere corpses. They are not inanimate, lifeless objects. There is a sense of life, a spirituality that I get from them. This is an important point for me. There is life after death, in a way. ${ }^{72}$

What we are suggesting, therefore, is an ethics of unsettlement in which photographs of human remains become the site of the participatory critique of legacies of epistemological violence and meditations on mortality. Photography is not the only medium for engaging in such a critique, but, as the example of Warhol's and Serrano's art suggests, the peculiar ambivalence of the photograph as transparent image which invites an experience of intimacy and even empathy, yet which confounds this invitation by virtue of its very mechanics of production and the possibility of infinite reproduction to the point of banality, makes it a peculiarly potent device for the affective disclosure and interrogation of our ways and techniques of knowing and representation, including those that have centred on the unearthing, study and display of human remains.

\section{Conclusion: Dead Images}

As we said at the beginning of this article, we have been brought together by 'dead images' and an ambition to create and curate an installation which features a lifesized photograph of a display of some 8,000 skulls, which through the nineteenth and into the twentieth centuries were collected from all around the world and transported to the Natural History Museum of Vienna, where they now reside, as part of a much larger collection of crania, perhaps over 40,000 in all. Although impressive in its size, this collection is not unusual. In cities all over Europe and North America there are similar collections, amassed during a time when the comparative study of crania was deemed central to the anthropological project of understanding the diverse physical forms of humans and, on the basis of that diversity, elaborating a now discredited analytic of race.

In 2012 Tal created a composite panorama of the skull cabinet, a photograph roughly thirty metres in length. During the three years before and five years after the image was captured (using the unconventional multi-perspective panorama method), Tal questioned and invited others to question and discuss the potentials and implications of exhibiting this photograph. What consolidated his early doubts into a deliberate and central dilemma was a wooden door in the middle of the long cabinet in his photograph. Behind this door was the historical photo laboratory 
of the anthropology department, established during the Nazi period by the then head of the department, Josef Wastl. Wastl saw great scientific value in photography and used it intensively, adding not only the dark-room and new photographic equipment but also many thousands of images to the department's photographic collection. His avid interest in photographic techniques went hand in hand with his obsession to increase the department's expertise and materials of racial research. He conducted research in various prisoner-of-war camps and on imprisoned Jews who were sent to the Buchenwald concentration camp on the same day that he completed his investigation. Of course, in addition to photographs and films, data sheets, handprints, footprints, hair samples and plaster-cast masks, Wastl obtained osteological material as well. Skeletons of Jews from Viennese cemeteries as well as skulls of concentration camp victims were added to the department's collections during this time. ${ }^{73}$

Nowadays, in the digital photography era, the old dark-room is not needed anymore, and instead the department houses its entire photographic collection in this room that opens directly from within the skull cabinet. The consolidation of these two collections - of skulls and of photographs - into one architectural framework provided Tal with the conceptual framework for considering his artistic process and interrogating the ethics of making and displaying a panoramic photograph of skulls. With these two very difficult collections, one inside the other, this is not only a photograph of a skull cabinet. The panorama depicts the history and different methods of scientific racism and evolutionary anthropology. For Tal, as a photographer, the production of a life-sized, high-resolution panoramic photograph became not only the work of fashioning an image but, in this, interrogating the field of photography itself, and especially its entanglement with race science. Inherent to the project is, therefore, a critical reflection on photography as a technique of dispossession and form of violence. As Tal reflects when discussing the process of photographing the display of crania,

It became clear for me that my use of photography in this project could not be taken for granted, or be excused with technical considerations alone. I needed to address photography's legacy, and define ethical questions for the use of photography in the context of scientific racial research and collections of human remains. ${ }^{74}$

This reflection on photography's legacy confronts us with a series of ethical dilemmas: does the photograph of row upon row of skulls reproduce the objectification of the dead? Should such a photography be displayed, given that it is impossible to secure the permission of the dead or their living ancestors? In the absence of any possibility of consent, does this making and planned display of such a photograph do hurt to the feelings of those who still have ancestral remains in this collection?

The exhibition of this photograph is a work in progress. It is scheduled to be constructed and made public in the summer of 2018. In undertaking this work, however, we have come to think about the ethical questions raised by the work of making and displaying an image of row upon row of skulls. If, as we are suggesting, 
we can extend our ethical concerns concerning the handling and display of 'real' human remains to the making and display of photographs of skulls, then these concerns include a concern with informed consent, dignity-in-process and managing the audience's encounter with a potentially powerful and unsettling image.

Our ambition in mounting this display is to extend this interrogation into the public sphere. This is an ethical project which must allow for concerns about dignity-in-process and audience sensibilities, yet must also allow for the disclosure of the ambivalence of the photograph as a peculiar kind of image whose transgressive potential hinges on the tension between intimacy and violence. We, as anthropologists, archaeologists and artists, are implicated in this work of transgression and must, in undertaking this work, be mindful of our purpose and conscious of our undertaking.

To show a picture of a Beothuk child exposed upon a plank of wood or a panoramic photograph of row upon row of skulls may be powerful. It may move the viewer. It may offer a sense of intimacy and proximity to a small body that no number of words could. Or it may impress with its scale and fascinate with the presentation of this mute skeletal diaspora. But it also implicates us, who discover or make such images and would choose to present it to the public, as well as any who view that image, in the long legacy of dispossession and violence which gave rise to the very possibility of that image and inhere in the circumstances of its making, storage and circulation. Such implication is inevitable, indeed central, to the ethical power of displays of human remains and dead images and their capacity to unsettle us.

\section{Notes}

1 Dead Images, one of five 'creative co-productions' which are part of a larger project, TRACES, which is exploring the potential of 'transmitting contentious cultural heritage with the arts. TRACES is supported by the European Union H2020-Reflective-Society funding scheme (GA 693857). For more information on TRACES and Dead Images see the website 'TRACES: transmitting contentious cultural heritage with the arts', www.traces.polimi.it/, accessed 7 December 2016.

2 J. P. Howley, The Beothucks or Red Indians (Cambridge, Cambridge University Press, 1915), pp. 231-2.

3 See D. Holly, 'The Beothuk on the Eve of Their Extinction', Arctic Anthropology, 37:1 (2000), 79-95; R. Pastore, 'The collapse of the Beothuk world', Acadensis XIX:1 (1989), 52-71; F. Rowe, Extinction: The Beothuks of Newfoundland (Toronto, McGraw-Hill Ryerson, 1977); and H. Horwood, 'The people who were murdered for fun', MacLean's Magazine, 10 October 1959, pp. 27, 36, 38, 40, 42-43.

4 For more on the unearthing of Beothuk remains see I. Marshall, History and Ethnography of the Beothuk (Montreal, Kingston, McGill-Queen's Press, 1996), pp. 398-410; S. Jerkic, 'Burials and Bones: A Summary of Burial Patterns and Human Skeletal Research in Newfoundland and Labrador', Newfoundland and Labrador Studies, 9:2 (1993), 213-34; and Howley, The Beothucks or Red Indians, pp. 330-6. 
5 The story of the circumstances of the discovery of the child's burial and the removal of the body and grave goods to St John's has been pieced together from three sources: Howley, The Beothucks or Red Indians, p. 331, Twillingate Sun, 20 November 1886, p. 4, and an article in a local history pamphlet found in the Robert's Arm Library: J. Anthony, 'Samuel Coffin (1833-1916): Businessman, Farmer, Ship-builder and Prospector', in W. Jackman, B. Warr and R. Bragg (eds), Remembrances of Roberts Arm: A Come Home Year 1995 Commemorative Book (Corner Brook, Western Star Publishers, 1995), p. 9. For a fuller account of this story see: J. Harries, 'A Beothuk Skeleton (not) in a Glass Case: Rumours of Bones and the Remembrance of an Exterminated People in Newfoundland - the Emotive Immateriality of Human Remains', in J. M. Dreyfus and É. Anstett (eds), Human remains in Society: Curation and Exhibition in the Aftermath of genocide and MASS-violence (Manchester, Manchester University Press, 2016).

6 J. P. Howley, 'Catalogue of the Specimens in the Museum', 1891 (Provincial Archive of Newfoundland and Labrador, James Patrick Howley fonds, MG 105), p. 75.

7 For a history of the Newfoundland Museum see: M. Bradshaw, 'The History of the Newfoundland Museum: The Past - the Present', The Trident, 4:1 (1977), 1, 3; and J. Maunder, 'Museum Notes - The Newfoundland Museum: Origins and Development' (1991), www.therooms.ca/museum/mnotes2.asp, accessed 7 December 2016. A fuller account of this history is given in Harries, 'A Beothuk Skeleton (not) in A Glass Case'.

8 Janus, University of Cambridge, Fisher Photograph Collection, 'Beothuk remains', https://janus.lib.cam.ac.uk/db/node.xsp?id=EAD\%2FGBR\%2F0115\%2FFisher\% 2011\%2F2489, accessed 7 December 2016.

9 A. H. Fisher, 'Beothuk Remains' (1908) (Cambridge University Library: Royal Commonwealth Society Collections, Fisher 11/2489).

10 S. H. Parsons, 'Beothuck Relics' (before 1908) (Provincial Archive of Newfoundland and Labrador, William J. Whiteway collection, A 34-158), http://gencat1.eloquent-systems.com/webcat/request/Action?ClientSession=9a65aa5:158d7e74ccb:-7fd7\&UniqueID=6000_3355_4\&TemplateProcessID = 6000_3355\&PromptID =\&ParamID =\&TemplateProcessID=6000_1051_1051\& PromptID $=\&$ ParamID $=\& C M D \_(\text {DetailRequest })[0]=\&$ ProcessID $=6000 \_$ 3363(0)\&KeyValues=KEY_45582, accessed 7 December 2016.

11 Howley, The Beothucks or Red Indians, p. 331.

12 B. Fardy, Demasduit: Native Newfoundlander (St John's, Nfld, Creative Publishers, 1988), p. 13.

13 Alfred Hugh Fisher came to Newfoundland in 1908 as an employee of the 'visual instruction committee' of the Colonial Office in London. His job was to travel the extent of the British Empire in order to take photographs that were destined to be integrated into lectures, illustrated with lantern slides, which served to cultivate an 'imperial attitude' in the children of Britain and the British colonies. The project itself was something of failure and it is unlikely that the photograph of the remains of the Beothuk child was ever included in a lecture for school children. For more information on the ambitions of the 'visual instruction committee' and Fisher's work see H. J. MacKinder, 'The Teaching of Geography from an Imperial Point of 
View, and the Use Which Could and Should Be Made of Visual Instruction', The Geographical Teacher, 6:2 (1911), 76-86, and J. R. Ryan, 'Visualizing Imperial Geography: Halford Mackinder and the Colonial Office Visual Instruction Committee, 1902-11', Cultural Geographies, 1:2 (1994), 157-76.

14 N. Márquez-Grant and L. Fibiger L. (eds), The Routledge Handbook of Archaeological Human Remains and Legislation. An International Guide to Laws and Practice in the Excavation and Treatment of Archaeological Human Remains (London, Routledge, 2011).

15 Ministry of Justice (MoJ), 'Application Form for a Licence to Remove Buried Human Remains (Including Cremated Remains)' (2012), www.gov.uk/ government/publications/apply-to-exhume-human-remains, accessed 29 November 2016.

16 See, for example, Museum of London Human Remains Working Group, Policy for the Care of Human Remains in Museum of London Collections (London: Museum of London, 2001), www.museumoflondon.org.uk/download_file/ view/1131/289, accessed 29 November 2016.

17 See, for example, BABAO Working-group for Ethics and Practice, British Association of Biological Anthropology and Osteoarchaeology Code of Ethics (2010), www.babao.org.uk/assets/Uploads/code-of-ethics.pdf, accessed 29 November 2016, and Department for Culture, Media and Sport (DCMS), Guidance for the Care of Human Remains in Museums (2005), www.britishmuseum.org/pdf/ DCMS\%20Guide.pdf, accessed 29 November 2016.

18 See, for example, World Archaeological Congress (WAC), The Vermillion Accord on Human Remains (2016), http://worldarch.org/code-of-ethics, accessed 29 November 2016.

19 See, for example, BABAO, Code of Ethics; WAC, The Vermillion Accord; and A. Fletcher, D. Antoine and J. D. Hill (eds), Regarding the Dead: Human Remains in the British Museum (2014), www.britishmuseum.org/PDF/Regarding-theDead_02102015.pdf, accessed 29 November 2016.

20 R. Joyce, 'Academic Freedom and Cultural Heritage', in C. Fforde, J. Hubert and P. Turnbull (eds), The Dead and Their Possessions. Repatriation in Principle, policy and Practice (New York, Routledge, 2002), pp. 99-107.

21 M. M. Brooks and C. Rumsey, 'The Body in the Museum', in V. Cassman, N. Odegaard and J. Powell (eds), Human Remains. Guide for Museums and Academic Institutions (Lanham, MD, Altamira Press, 2007), pp. 261-89.

22 See T. Jenkins, Contesting Human Remains in Museum Collections (New York, Routledge, 2011), and J. R. Sofaer, The Body as Material Culture. A Theoretical Osteoarchaeology (Cambridge, Cambridge University Press, 2006).

23 Brooks and Rumsey, 'The Body in the Museum'.

24 English Heritage, Research into Issues Surrounding Human Bones in Museums (2009), https://content.historicengland.org.uk/content/docs/research/opinionsurvey-results.pdf, accessed 29 November 2016.

25 Brooks and Rumsey, 'The Body in the Museum', p. 283.

26 E. K. Wilson, 'The Collection and Exhibition of a Fetal and Child Skeletal Series', Museum Anthropology, 38:1 (2015), 15-27. 


\section{John Harries et al.}

27 National Museum of Ireland, 'Kingship and Sacrifice', www.museum.ie/ Archaeology/Exhibitions/Current-Exhibitions/Kingship-and-Sacrifice, accessed 29 November 2016.

28 H. Williams and A. Atkin, 'Virtually Dead: Digital Public Mortuary Archaeology', Internet Archaeology, 40, https://doi.org/10.11141/ia.40.7.4, accessed 28 June 2017.

29 DCMS, Guidance for the Care of Human Remains in Museums, p. 20.

30 D. Antoine, 'Curating Remains in Museum Collections. Broader Considerations and a British Museum Perspective', in A. Fletcher, D. Antoine and J. D. Hill (eds), Regarding the Dead: Human Remains in the British Museum (2014), pp. 3-9, p. 6, www.britishmuseum.org/PDF/Regarding-the-Dead_02102015.pdf, accessed 29 November 2016.

31 K. L. Walton, 'Transparent Pictures: On the Nature of Photographic Realism', Critical Inquiry, 11:2 (1984), 246-77, 250.

32 A. Bazin and H. Gray, 'The Ontology of the Photographic Image', Film Quarterly, 13:4 (1960), 4-9.

33 Walton, 'Transparent Pictures', 247-9.

34 Ibid., 251.

35 M. Pettersson, 'Depictive Traces: On the Phenomenology of Photography', The Journal of Aesthetics and Art Criticism, 69:2 (2011), 185-96, 186.

36 S. Sontag, On Photography (New York: Rosetta Books, 2005), p. 71, https://archive.org/details/On_Photography, accessed 8 December 2017.

37 R. Barthes, Camera Lucida: Reflections on Photography, trans. R. Howard (New York, Hill and Wang, 1981), pp. 80-1.

38 Pettersson, 'Depictive Traces', 189.

39 Ibid., 191.

40 Ibid., 193.

41 Ibid., 189.

42 Sontag, On Photography, p. 2.

43 See F. Nudelman, 'Against Photography: Susan Sontag's Vietnam', Photography and Culture, 7:1 (2014), 7-20.

44 See P. Landau, 'Empires of the Visual: Photography and Colonial Administration in Africa', in P. Landau and D. Kapsin (eds), Images and Empires: Visuality in Colonial and Postcolonial Africa (Berkeley and Los Angles, University of California Press, 2002), pp. 141-71.

45 See A. Maxwell, Colonial Photography and Exhibitions: Representations of the Native and the Making of European Identities (London, Leicester University Press, 2000), and J. R. Ryan, Picturing Empire: Photography and the Visualization of the British Empire (London, Reaktion Books, 2013).

46 W. Modest, 'Museums and the Emotional Afterlife of Colonial Photography', in E. Edwards and S. Lien (eds), Uncertain Images: Museums and the Work of Photographs (London and New York, Routledge, 2016), pp. 21-42.

47 E. Edwards and M. Mead, 'Absent Histories and Absent Images: Photographs, Museums and the Colonial Past', Museum and Society, 11:1 (2013), 19-38, 19.

48 See P Bijl, 'Colonial Memory and Forgetting in the Netherlands and Indonesia, Journal of Genocide Research, 14:3-4 (2012), 441-61, and A. L. Stoler, 'Colonial 
Aphasia: Race and Disabled Histories in France', Public Culture, 23:1 (2011), 121-56.

49 Modest, 'Museums and the Emotional Afterlife', pp. 29-30.

50 P. Pattynama, 'The Story of the Netherlands-Indies: The Use of Photographs in the Centre of Indies Remembrance', in E. Edwards and S. Lien (eds), Uncertain Images: Museums and the Work of Photographs (London and New York, Routledge, 2016), pp. 133-48; P. Bijl, Emerging Memory: Photographs of Colonial Atrocity in Dutch Cultural Remembrance (Amsterdam, Amsterdam University Press, 2015); Modest, 'Museums and the Emotional Afterlife'.

51 Bijl, 'Colonial Memory and Forgetting, 458.

52 P. Bijl, 'Embodying Colonial Photography: Remembering Violence in Tabee Toean', Depth of Field, 1:1 (2011), https://pure.uva.nl/ws/files/1814477/128371_375356. pdf, accessed 30 June 2017.

53 E. Edwards and S. Lien, 'Museums and the Work of Photography', E. Edwards and S. Lien (eds), Uncertain Images: Museums and the Work of Photographs (London and New York, Routledge, 2016), pp. 3-20, pp. 4-5.

54 E. Stylianou and T. Stylianou-Lambert, 'Approaches to Displaying the Dead in Museums', in E. Stylianou and T. Stylianou-Lambert (eds), Museums and Photography: Displaying Death (London and New York, Routledge, 2017), pp. 1-18, pp. 11-13.

55 J. Bennett, Empathic Vision: Affect, Trauma and Contemporary Art (Stanford, CA: Stanford University Press, 2005), p. 7, quoted in Stylianou and Stylianou-Lambert, 'Approaches to Displaying the Dead in Museums', p. 11.

56 J. D. Hammond, 'Photography and Ambivalence', Visual Studies, 19:2 (2004), 135-45, 135. For a further discussion of the ethics of ethnographic photography see: S. Perry and J. S. Marion, 'State of the Ethics in Visual Anthropology', Visual Anthropology Review, 26:2 (2010), 96-104.

57 Hammond, 'Photography and Ambivalence', 135.

58 Ibid.

59 Ibid.

60 S. Langmann and D. Pick, 'Dignity and Ethics in Research Photography', International Journal of Social Research Methodology, 17:6 (2014), 709-21, 713.

61 See L. Kunde, E. McMeniman and M. Parker, 'Clinical Photography in Dermatology: Ethical and Medico-legal Considerations in the Age of Digital and Smartphone Technology', Australasian Journal of Dermatology, 54:3 (2013), 192-7, and R. Van der Rijt and S. Hoffman, 'Ethical Considerations of Clinical Photography in an Era of Emerging Technology and Smartphones', Journal of Medical Ethics, 40:3 (2014), 211-12.

62 I. Berle, 'Clinical Photography and Patient Rights: The Need for Orthopraxy', Journal of Medical Ethics, 34:2 (2008), 89-92, 89.

63 Ibid., 90.

64 Ibid.

65 I. Berle, 'The Ethical Context of Clinical Photography', Journal of Audiovisual Media in Medicine, 25:3 (2002), 106-9, 107. 
66 T. T. Beauchamp and J. F. Childress, Principles of Biomedical Ethics (Oxford, Oxford University Press, 2001), p. 5.

67 See D. W. Riggs and E. Peel, Critical Kinship Studies: An Introduction to the Field (Basingstoke: Palgrave Macmillan, 2016), pp. 39-47.

68 D. Sayer, 'Who's Afraid of the Dead? Archaeology, Modernity and the Death Taboo', World Archaeology, 42:3 (2010), 481-91, 488.

69 Ibid.

70 Sontag, On Photography, p. 1.

71 A. Warhol, Death and Disasters (Houston, TX: Houston Fine Art Press, 1988). For a discussion of death, mortality and Warhol's art see: H. Foster, 'Death in America', October, 75 (1996), 37-59.

72 A. Blume and A. Serrano, 'Andres Serrano', BOMB, 43 (1993), 36-41.

73 See M. Berner, 'Race and Physical Anthropology in Interwar Austria', Focaal, 58 (2010), 16-31, and K. Matiasek, 'A Mutual Space? Stereo Photography on Viennese Anthropological Expeditions (1905-45)', in M. Klemun and U. Spring (eds), Expeditions as Experiments (London: Palgrave Macmillan, 2016), pp. 187-212.

74 R. Lichtzier, 'Dead Images // Tal Adler', The Seen, 3 (2016), 114-19, 115, http://theseenjournal.org/wp-content/uploads/2016/09/TheSEEN_Publication_Issue-03_for_Web.pdf, accessed 9 December 2017. 